\title{
Extraordinary snow accumulations over parts of central Europe during the winter of 2005/06 and weather-related hazards
}

Article

Published Version

Pinto, J. G., Brücher, T., Fink, A. H. and Krüger, A. (2007) Extraordinary snow accumulations over parts of central Europe during the winter of 2005/06 and weather-related hazards. Weather, 62 (1). pp. 16-21. ISSN 1477-8696 doi: https://doi.org/10.1002/wea.19 Available at https://centaur.reading.ac.uk/32791/

It is advisable to refer to the publisher's version if you intend to cite from the work. See Guidance on citing.

Published version at: http://dx.doi.org/10.1002/wea.19

To link to this article DOI: http://dx.doi.org/10.1002/wea.19

Publisher: Wiley

All outputs in CentAUR are protected by Intellectual Property Rights law, including copyright law. Copyright and IPR is retained by the creators or other copyright holders. Terms and conditions for use of this material are defined in the End User Agreement.

www.reading.ac.uk/centaur 
Central Archive at the University of Reading

Reading's research outputs online 


\section{Extraordinary snow accumulations over parts of central Europe during the winter of 2005/06 and weather-related hazards}

\section{Joaquim G. Pinto, Tim Brücher, Andreas H. Fink, Andreas Krüger \\ Institute for Geophysics and \\ Meteorology, University of Cologne}

During the winter of 2005/06, record-breaking snow accumulations were observed in many locations in south-east Germany, large parts of Austria and in the low mountain ranges along the Czech/German as well as Czech/Austrian borders. In the lowlands, low mountain ranges and eastern Alpine valleys of the above-mentioned study area, the snow mantle reached its maximum depth in early to mid-March, with many stations reporting snow depths between 40 and $60 \mathrm{~cm}$ in the morning hours of 7 March 2006 (Figure 1), with a few readings of more than $100 \mathrm{~cm}$, e.g. Lunz am See $139 \mathrm{~cm}$ (Eastern Alps, Austria, altitude of $615 \mathrm{~m}$ above sea-level (a.s.I.)) and Zinnwald-Georgenfeld $150 \mathrm{~cm}$ (Erz Mountains, Germany, $882 \mathrm{~m}$ a.s.l.). Shortly after this date, widespread snow depths of more than $100 \mathrm{~cm}$ were also observed in the Bavarian and Bohemian Forests and the Austrian Forest Quarter. The picture taken at Neureichenau (Bohemian Forest, Germany) on 12 March 2006 gives a good impression of the landscape buried under the deep snow (Figure 2). As seen in the picture, local residents had to remove the snow from the roofs of their houses to avoid collapse. The winter of 2005/06 was not only notable in terms of the snow depth at the end of the winter season, but also in terms of snow-cover duration and intermittent heavy snowfall events in the low-lying areas of the study region. Among the most momentous weather-related hazards were the collapse of several roofs under the heavy weight of the snow. For example, the breakdown of the dome of an ice skating hall at Bad Reichenhall (Germany) on 2 January killed 15 people and injured over 50.

As many winters in the last two decades were unusually mild and, consequently, marked by a poor snow cover, the winter of $2005 / 06$ was perceived by the local residents as being extremely snowy, cold and long. People will commemorate the winter of 2005/06 as being the severest in decades; at some locations the severest within living memory. In the present contribution, we will highlight that from the climatological standpoint the winter was neither unusually wet nor cold, but characterised by the absence of significant thawing episodes. We will relate this to the anomalous frequency and persistence of two particular circulation weather types. This article will also give a more detailed account of the weatherrelated hazards and will briefly discuss if this type of extreme weather is likely to be expected more frequently in the future. For these aspects, the winter period is defined as the time from the beginning of October to the end of March.
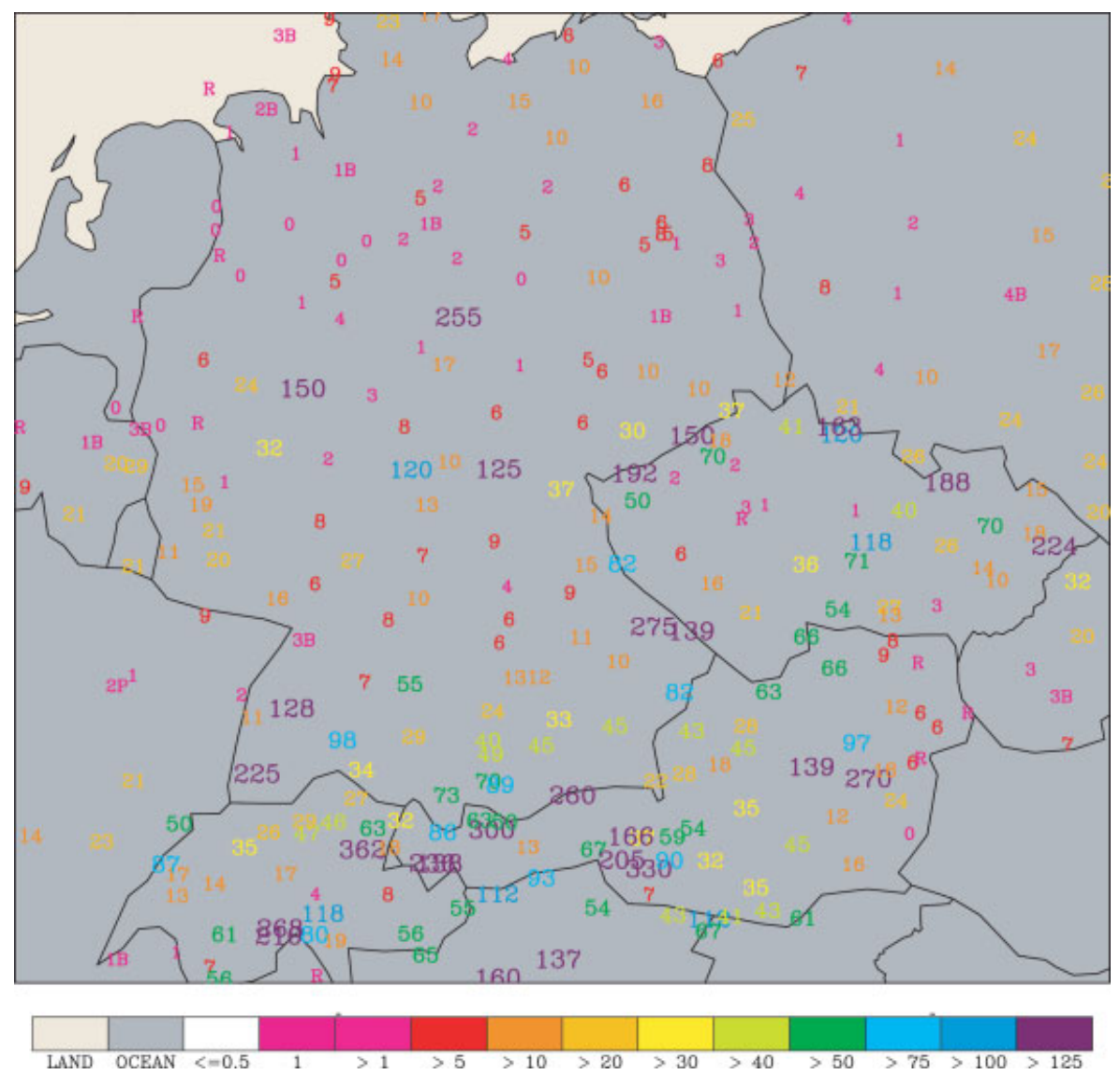

Figure 1. Snow depth over central Europe for 7 March 2006. All values given in $\mathrm{cm}$.

\section{The winter of $2005 / 06$}

The unusual snow cover was mainly caused by the persistence of temperatures below freezing throughout the snow accumulation period between early December 2005 and mid-March 2006. As a consequence, December to March screen temperatures were slightly below average (around $-1 \mathrm{deg} C$ ) in the area under investigation (Figure3(a), reference period 1961-1990). However, from the climatological perspective, the winter of 2005/06 was certainly not extreme in terms of low temperatures. As is evident from the long central European winter time-series of the stations De Bilt (The Netherlands), Potsdam (Germany), Basel (Switzerland) and Vienna (Austria), 


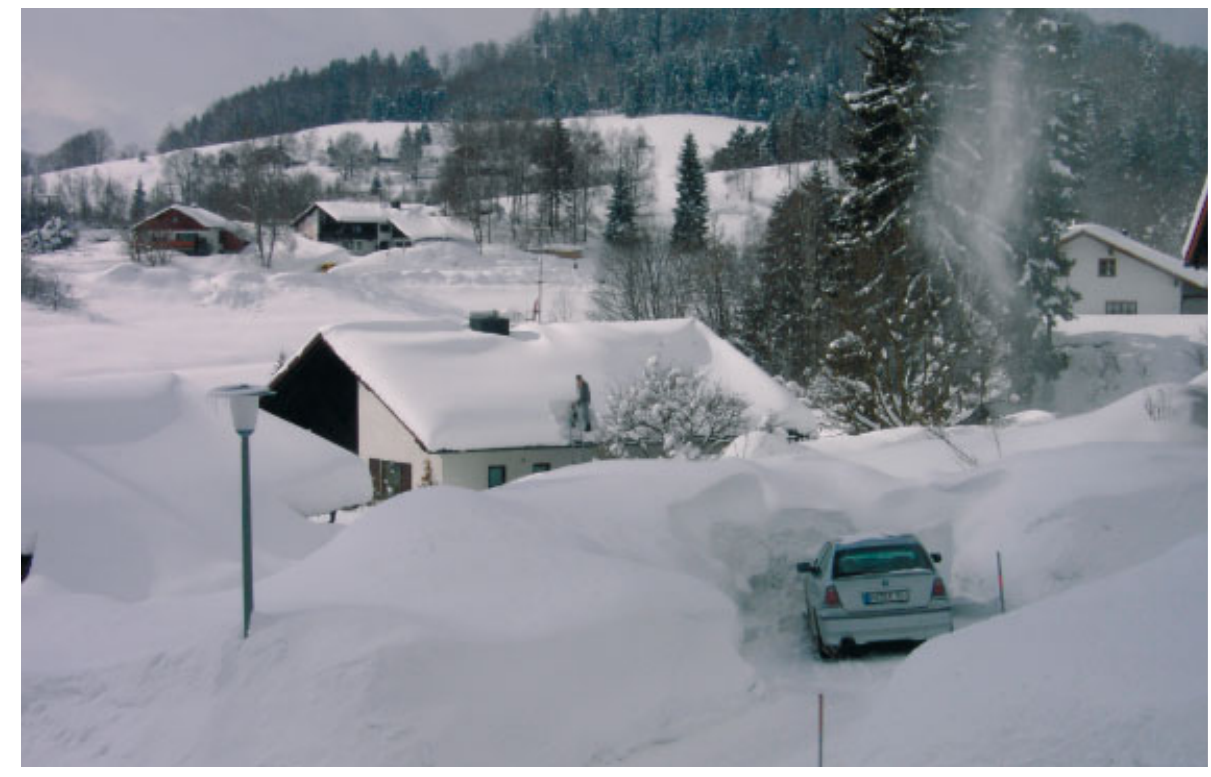

Figure 2. Landscape under a deep snow cover. Photo taken on 12 March 2006 at Neureichenau (Bohemian Forest, Germany).

only winters with December to February average-temperature anomalies over all four stations below -3 degC rank in the lowest decile of the distribution (cf. http:// www.uni-koeln.de/math-nat-fak/ geomet/meteo/Klimastatistik/baurtemp wintergross.gif). The anomaly for the winter $2005 / 06$ is $0.0 \mathrm{deg}$.

Moreover, accumulated precipitation values were slightly below average over south-central Europe for the December thousands of people had to be evacuated. Further downstream of the River Danube, Hungary was also particularly affected, where a record gauge level of $8.61 \mathrm{~m}$ was measured at Budapest on 8 April 2006, the highest level for 120 years.

In our detailed analysis of temperature and precipitation evolution during this winter, we will focus on the regions of southeast Germany and north-east Austria, with a particular emphasis on the foreland of the eastern Alps. October 2005 was extremely warm and sunny over central Europe. The temperature anomaly for the above-noted four central European cities was $+2.8 \mathrm{degC}$. Temperature dropped quite abruptly around 20 November when the first winter snow fell in this area. In the Austrian states of Carinthia and southern Salzburg, the onset of the snow-cover season 2005 will be remembered for a long time; in the 24 hours to 0600 UTC on 27 November new records were set when $57 \mathrm{~cm}$ and $56 \mathrm{~cm}$ of fresh snow fell at Villach (494 ma.s.l.) and St Michael/Lungau (1094 $\mathrm{m}$ a.s.l.), respectively, after a preceding period of unusual warmth. The total snow depths of $76 \mathrm{~cm}$ and $48 \mathrm{~cm}$ on 27 November 2005 respectively at Villach and Klagenfurt ( $476 \mathrm{~m}$ a.s.l.), also constitute all-time records. The accumulated sum of fresh-fallen snow at Villach in November 2005 reached $72 \%$ of the mean winter season average (cf. http://www.zamg.ac.at). The onset of the winter will also be remem- (a)

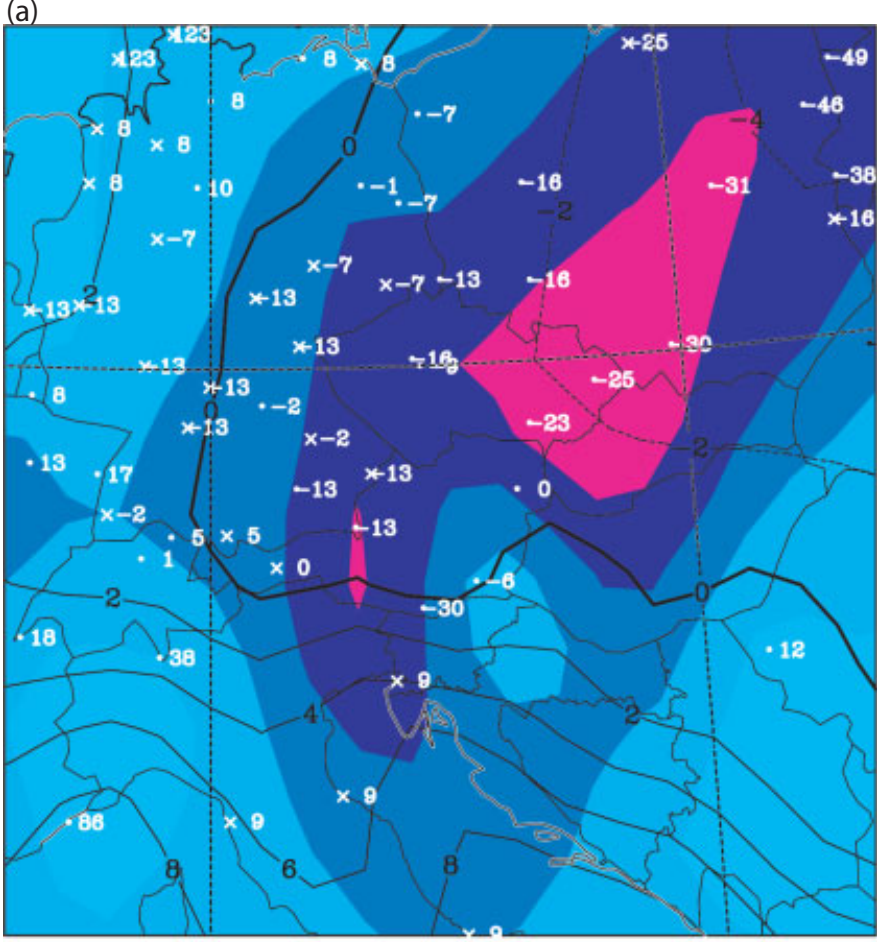

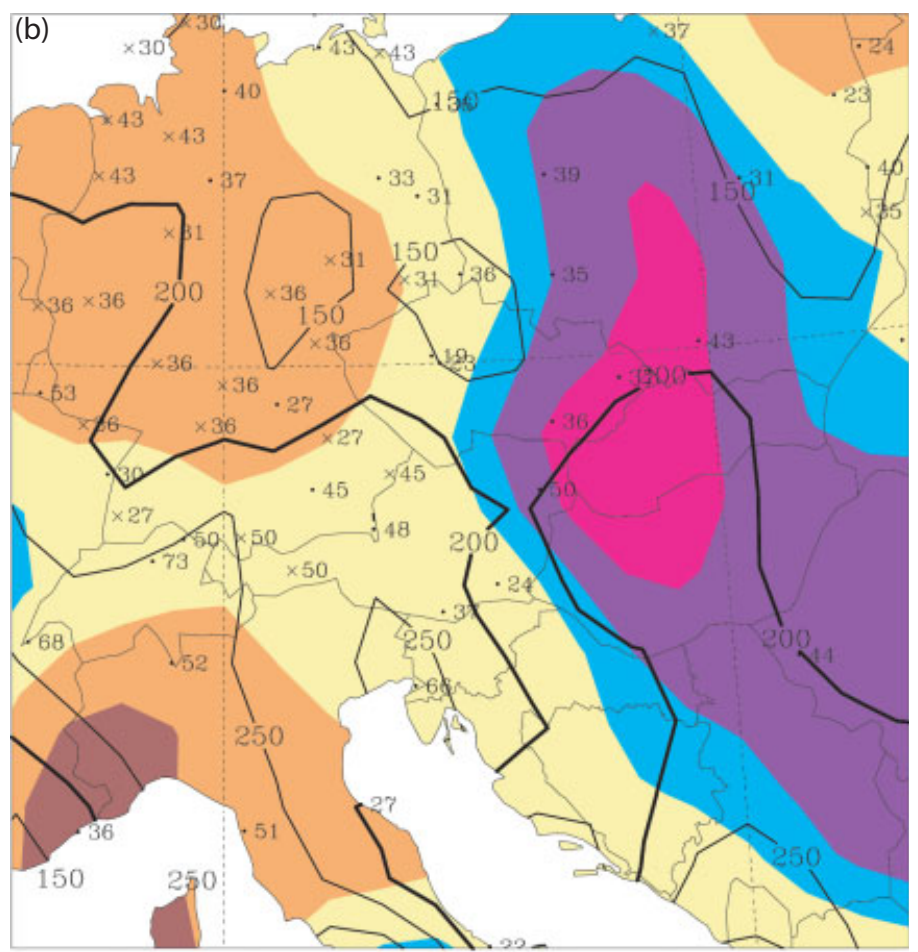

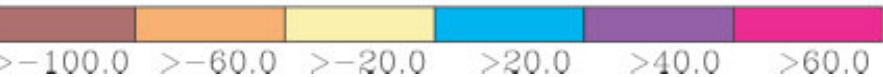
$>-2.500>-2.000>-1.500>-1.000>-0.500$ Figure 3. Temperature and accumulated precipitation anomalies for central Europe, December 2005 through March 2006. (a) temperature (in one-tenth of a degC);
black lines indicate the average field, coloured areas show anomaly values. (b) accumulated precipitation (in mm); black lines indicate the average field, coloured areas show anomaly values. Reference period is 1961-1990. 
bered in Germany and parts of The Netherlands for another costly snowstorm. On 25 November 2005, a low pressure system over The Netherlands dropped more than $30 \mathrm{~cm}$ of wet snow in north-west Germany and the eastern Netherlands causing, along with strong winds, the buckling of numerous power lines and widespread power outages.

As may be seen from the snow-cover data from Passau/Fürstenzell* (Germany, $476 \mathrm{~m}$ a.s.I.) in Figure 4(a), the snow-cover season started on 18 November (the climatological mean date is 20 November). It was not until the turn of the year that an anomalous snow cover began to develop. Major snowfall events occurred in the second half of December, around 2-3 January, 17-18 January, 7-9 February, 2-3 March, and 8-9 March (Figure 4(a)). Daily mean temperatures remained below freezing throughout most of the four-month period between 20 November 2005 and 20 March 2006 (Figure 4(a), red curve). Thawing episodes were short-lived and weak, except for two: one between 19 and 22 February, and another on 10-11 March. Aside from the above-mentioned heavy snowfall events, it was the infrequency and weakness of the thawing episodes that allowed the snow cover to increase at Passau/Fürstenzell to its peak value of $82 \mathrm{~cm}$ on 7 March 2006. In terms of temperature deviations, January and February were the coldest in the region. Passau/Fürstenzell and Mühldorf on the River Inn (Germany, 405 ma.s.I.) reported average temperature deviations for January of $-3.2 \operatorname{deg} C$ and $-2.9 \operatorname{deg} C$, and for February values were $-2.4 \mathrm{degC}$ and $-2.7 \mathrm{degC}$, respectively. Figure 4(b) clearly shows that the accumulated precipitation was below the 1948-2004 average throughout the entire accumulation period at Passau/Fürstenzell. This finding corroborates our thesis that the absence of melting periods was the major cause of the unusual snow depth later in the winter. The snow depths reached values of about 6-7 times above average with respect to the reference period of 1948-2004 for early February, and up to 10 times above average for early March (see also snow-depth readings in Figure 1). In March, all synoptic stations in Bavaria still reported over 20 days of daily minimum temperatures below zero (frost days). The third and final thawing phase started after 18-19 March. As seen from the temperature curve in Figure 4(a), dailymean temperatures rose up to $10^{\circ} \mathrm{C}$ at the end of the month, accompanied by rainfall observed on daily basis (Figure 4(b)). By the

* The time-series of Passau-Oberhaus and Fürstenzell were combined, because the observations at Passau-Oberhaus end at 3 January 1997 and were continued at Fürstenzell by the DWD.

(a)

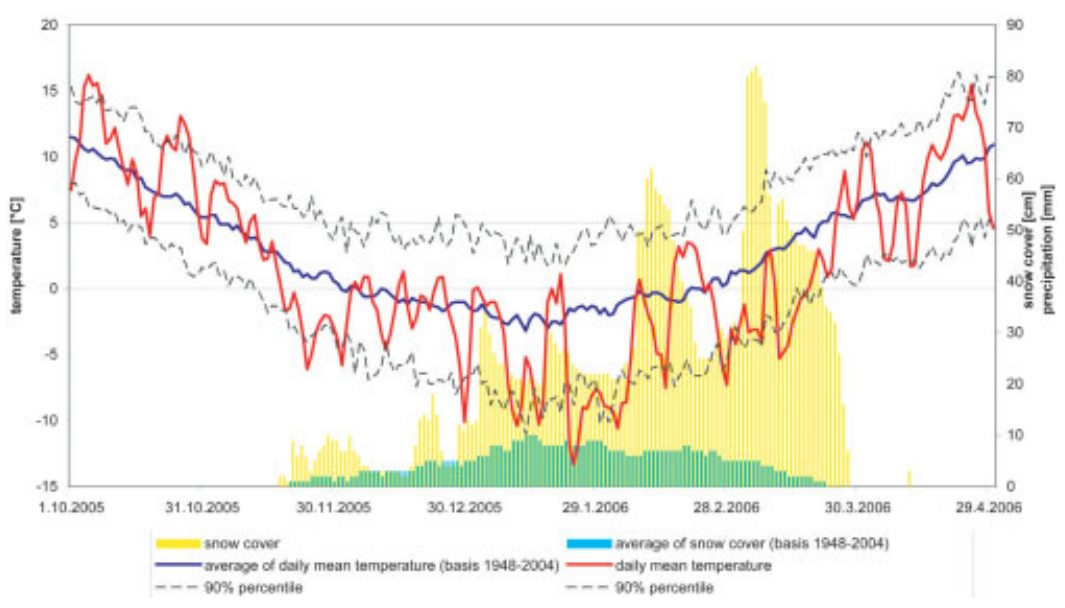

(b)

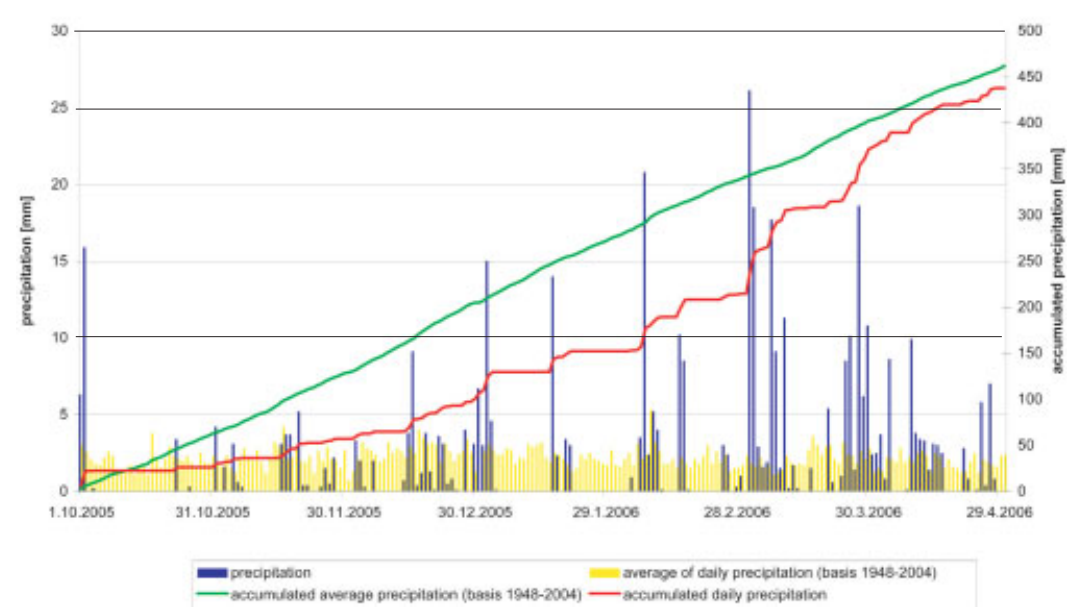

Figure 4. Synoptic development in Passau/Fürstenzell for the winter 2005/06 in terms of (a) mean temperature (red curve, ${ }^{\circ} \mathrm{C}$ ) and snow cover (yellow bars, $\mathrm{cm}$ ). Blue lines: long- term average mean temperature and 90th percentile values (1948-2004, $\left.{ }^{\circ} \mathrm{C}\right)$. Blue bars: average snow cover $(1948-2004, \mathrm{~cm})$ (b) daily and accumulated precipitation (blue bars and red curve, respectively). Yellow bars: average daily precipitation (1948-2004). Green curve: accumulated average precipitation (1948-2004). All values are given in $\mathrm{mm}$.

end of the month, snow had melted within a week in the area of interest (eg. Rudolf and Matthäus, 2006) and only stations with altitudes above $800 \mathrm{~m}$ reported remaining snow. As discussed below, snow-melt and rainfall caused major flood waves in rivers. Similar developments of snow cover and melting were observed in parts of Austria and the Czech Republic.

\section{Synoptic weather types and blocking in the winter of 2005/06}

In this section, we will analyse the synoptic reasons for this long spell of cold weather, which contributed to the unusual persistence and depth of the snow cover over the study region. To achieve this goal, we will use the subjective "Grosswetterlagen" (GWLs, cf. also Fink et al., 2004). This classi- fication of circulation weather types includes $30 \mathrm{GWLs}$, which describe typical cyclonic, anticyclonic and neutral weather patterns for central Europe. They are subjectively determined for each calendar day on the basis of surface pressure and, since available, 500 mbar charts. These statistics extend backward in time for almost 130 years and are published and updated by the German Weather Service (Hess and Brezowsky, 1977).

October and the first half of November of 2005 were fairly warm and dry. The sudden onset of wintry conditions around 18 November was associated with the occurrence of the GWL 8 'North-west cyclonic' (16-21 November). Figure 5(a) depicts the average surface (mean sea-level pressure) and mid-tropospheric (500 mbar geopotential height) conditions associated with GWL 8 for the winter of 2005/06. This synoptic pattern brings cool and moist air from the 
North Sea that gives rise to partly orographically enhanced precipitation at temperatures somewhat below freezing. Later in November, the GWL 17 'Trough Central Europe' (25-30 November) was identified. Figure 5(b) displays a surface low over German Bight and a trough over central Europe that was associated with GWL 17 during the winter. The associated synoptic situation kept the temperatures well below freezing with a concurrent precipitation accumulation close to average (Figure 4(b)).

It was the anomalous frequency of these two GWLs that caused the persistent cold spell and intermittent heavy snowfall events during the coming weeks. When combined, the two GWLs occurred three times as often as in a normal October-through-March period, being present on about $30 \%$ of days between October 2005 and March 2006. From 13 December to 4 January, the synoptic weather pattern over Europe was first GWL 8, shifting to GWL 17 after 26 December and significant snowfall events happened during this period (Figure 4(a)). The snowfall between 7 and 9 February was associated with GWL 8, whereas the snowfall event in early March was associated with GWL 17. Over the whole winter, these two weather types contributed $65 \%$ and $55 \%$ of the total snowfall for the Austrian stations of Lunz am See and Lillienfeld/Sulzer (696 m a.s.l.), respectively.

Another GWL that was anomalously frequent during the winter of 2005/06 was 'south-west cyclonic' (GWL 6). As can be understood from the surface and midtropospheric flow conditions displayed in Figure 5(c), this GWL carries mild and moist air from the Bay of Biscay region to central Europe. GWL 6 was responsible for the positive temperature anomalies until the middle of November. Daily mean temperature at the Zugspitze mountain (Germany, northern Alps, 2962 ma.s.l.) fluctuated around freezing until it dropped significantly when GWL 8 set in the second half of November 2005 (Figure 6) The increase in temperature after 24 March was also associated with the occurrence of GWL 6 (24-31 March). By 29 March, all snow had melted at Passau/ Fürstenzell (see Figure 4(a)). Between late March and mid-April, a succession of depressions crossed over central Europe and brought regular rainfall over south-east Germany, the Czech Republic and Austria, particularly between 9-13 April associated with GWL 17.

As expected, the frequencies of the two most important zonal, i.e. westerly synoptic weather types (GWLs 1 and 2) were extremely low: while their normal relative frequency is about $20 \%$, it was only $1 \%$ during this winter. The substantial deficit in zonal vs. meridional circulation patterns can be quantified objectively by means of the blocking index of Tibaldi and Molteni (1990). (a)
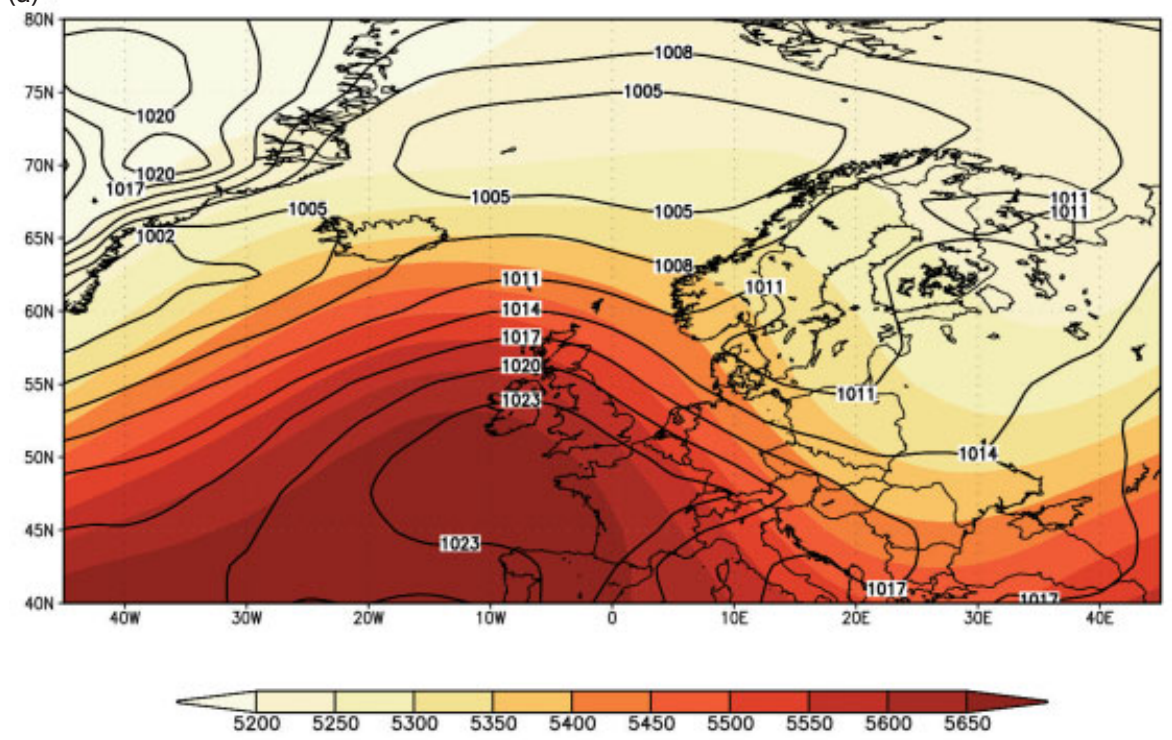

(b)

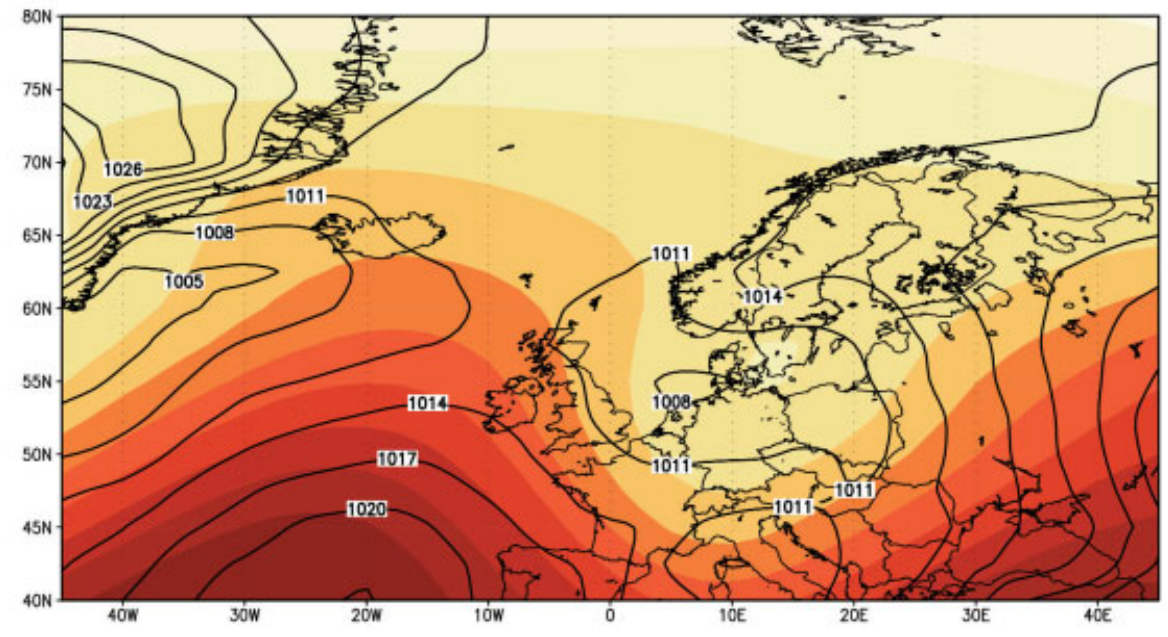

\begin{tabular}{cccccccccccc}
\hline & $\frac{1}{1}$ & $\frac{1}{1}$ & & & & & & & \\
5200 & 5250 & 5300 & 5350 & 5400 & 5450 & 5500 & 5550 & 5600 & 5650
\end{tabular}

(c)
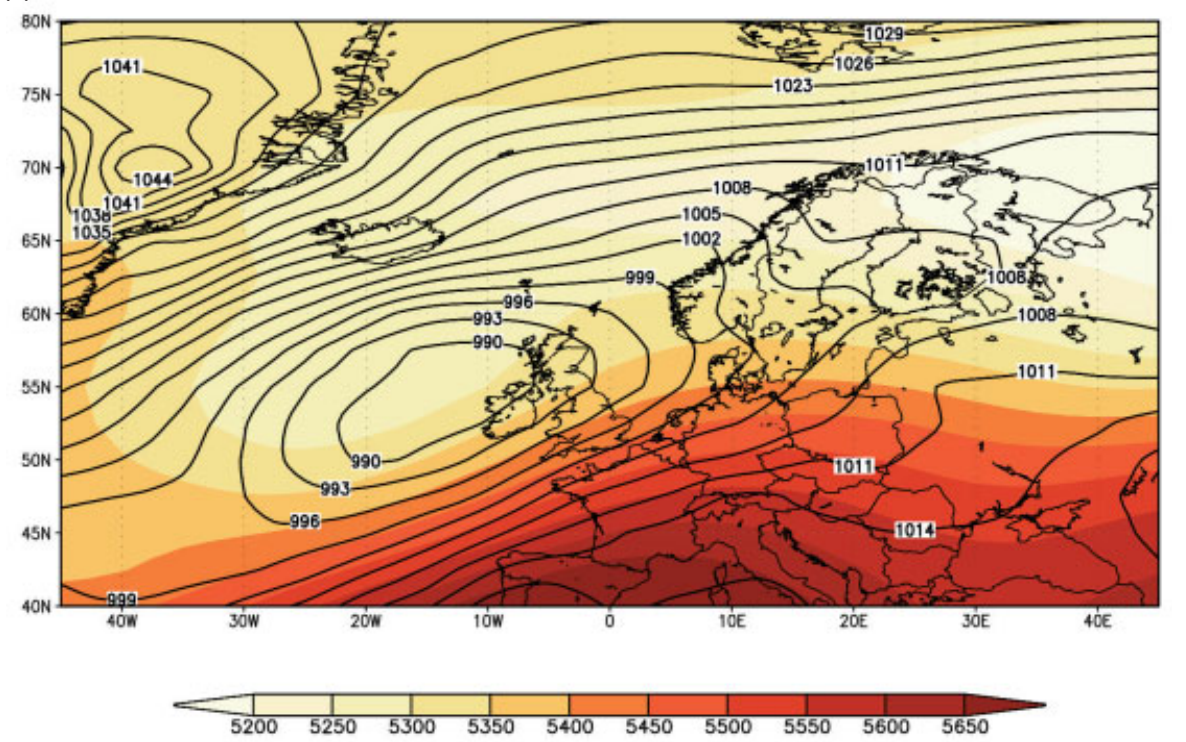

Figure 5. Average surface (mean sea-level pressure) and mid-tropospheric (500 mbar geopotential height) conditions associated with GWLs for the winter of 2005/06 (a) GWL 8 (b) GWL 17 (c) GWL 6. Black lines correspond to the MSLP field, coloured values to the $500 \mathrm{mbar}$ field. Isoline interval is 3 mbar for MSLP and $50 \mathrm{gpm}$ for 500 mbar geopotential.

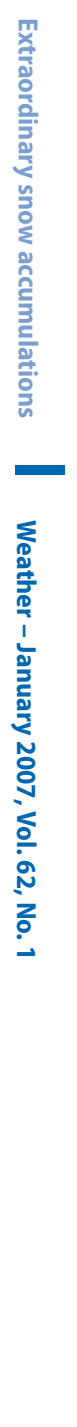


In this winter, the atmospheric blocking was indeed much increased over the north Atlantic and Europe $\left(30^{\circ} \mathrm{W}-40^{\circ} \mathrm{E}\right.$, Figure 7), particularly over central Europe; between $10^{\circ}-30^{\circ} \mathrm{E}$, the blocking index values exceed the 95th percentile values of the period 1948-2005. Similar results have been obtained by Folland et al., (2006), who related this to the negative NAO phase during the winter $2005 / 06$. The role of the NAO was further analysed by Saunders and Lea (2006), who explored its implications for the belowaverage temperatures over central Europe during the period December 2005 to February 2006. Interestingly, this anomaly affected only the European sector of the northern hemisphere (Figure 7). For other areas, no anomalous blocking was observed, in fact, the flow over the northern Pacific around $200^{\circ} \mathrm{W}$ during the winter was anomalously zonal.

\section{Weather-related hazards and spring floods}

There were a large number of weatherrelated hazards due to the snowfall events in southern Germany and Austria between the last week of December 2005 and the first week of March 2006. Several roofs in southern Bavaria and Austria collapsed during this time. Collapsed roofs were also reported from the cities of Salzburg, Fischamend, Eugendorf/Flachgau and Stadl-Paura (all Austria) on 3 January. At the same day, the nearby German village of Ruhpolding recorded $45 \mathrm{~cm}$ of fresh snow. Additionally, the roof of the major hall collapsed in Mariazell (Austria) on 25 January. On 11 February, Lillienfeld and Lunz am See were particularly hit by heavy snowfall, and their vicinities were declared as 'disaster areas' (Upper Styria and Mariazellerland, respectively). During the last major snowfall event, a flat roof of a storehouse collapsed under the weight of the snow in Unterweißenbach (near Freistadt, Forest Quarter, Austria) on 8 March. Larger damage could only be avoided as civil protection and fire brigades helped the local inhabitants to clean roofs of snow and evacuate endangered buildings. During most of the winter, there was an enhanced danger of land/snow slides and of snow/ice-covered roads, which seriously disrupted the traffic in this area and caused a few human casualties, mostly in association with road accidents. Many roads were also blocked by fallen trees, and there were numerous problems with power outages due to breakdowns of power lines, too (eg. St. Aegidi, Schärding, Klagenfurt and Villach, all Austria). The forests in Lower Austria (Mostviertel and Mühlviertel) were also severely damaged.

Additionally, the boat traffic on the River

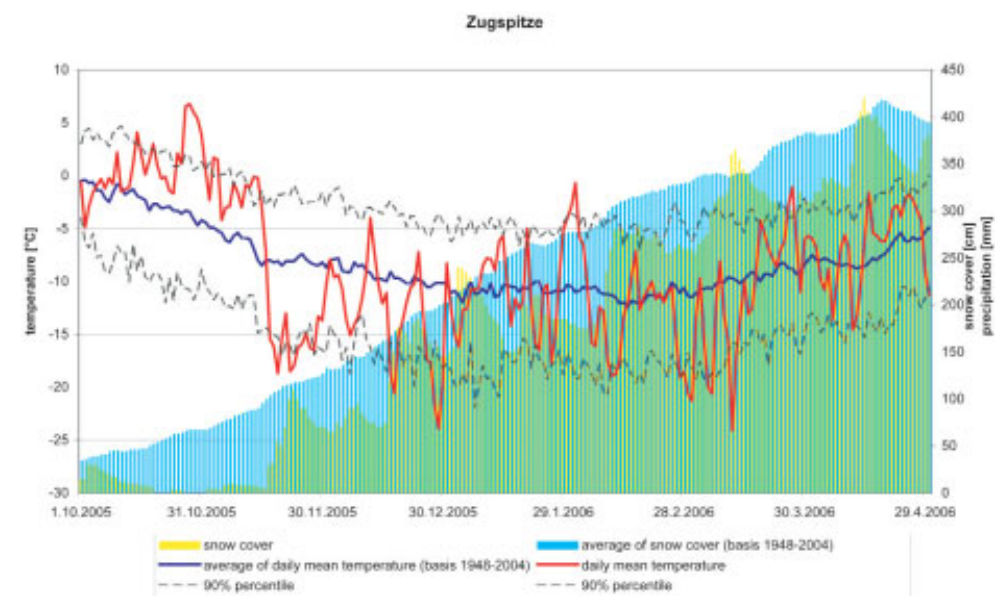

Figure 6. As Fig. 4(a) but for the Zugspitze

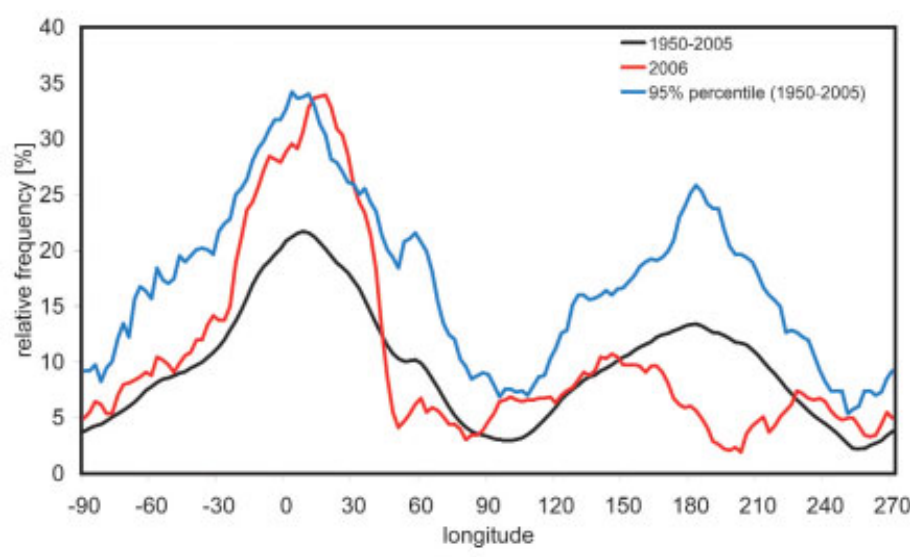

Figure 7. Blocking index for the Northern Hemisphere mid-latitudes for the winter 2005/06. Values are computed on a daily basis and are given as relative frequencies versus longitude. Red Line: values for the winter 2005/06; Black line: NCEP mean value for 1950-2005; Blue line: upper 95th percentile value for 1950-2005.

March due to thick river ice cover. The ensuing snowmelt led to extensive floods in Danube and Elbe rivers. The first flood wave in the River Danube was observed around 19 February, followed by a second sharp flood wave around 12 March, and a third one around 29 March. These dates correspond to the passage of the peak water level at Passau (Figure 8). It is noteworthy that these flood waves in the River Danube match well with the three thawing events reported earlier and that the occurrence of these floods is primarily attributable to snow melt. This is especially true for the first two events. The last flood wave was further enhanced by extensive rainfall in late March and strongly affected not only the River Danube, but also the Elbe and Moravia rivers until early April. As a result, flood conditions were reported along sections of these rivers in the Czech Republic, Germany, Austria, and Hungary. In the Czech Republic, a total of 45 cities and more than 20 rivers were affected. In the German/Czech border town of Schöna, the water level of the upper Elbe rose from $3 \mathrm{~m}$ on 27 March to a peak value of $8.88 \mathrm{~m}$ in the night between 3 and 4 April (Rudolf and Matthäus, 2006). Moreover, about 1000 people had to be evacuated along the Czech-German border. In Germany, the Elbe was higher at some locations than during the flood of 2002, eg. in Hitzacker $(7.60 \mathrm{~m})$, Boizenburg and Doemitz. In Dresden, however, the water level was significantly lower than in 2002 ( $7.48 \mathrm{~m}$ versus $9.40 \mathrm{~m}$, cf. Rudolf and Matthäus, 2006). In Austria, three dams broke during the first week of April and 516 people had to be evacuated. In the following days, Slovakia and Hungary were also severely affected. In addition to the recordbreaking flood peak in Budapest, which surpassed the level reached in the floods of 2002 , over 170000 hectares of land in the Hungarian great plains were under water. Furthermore, smaller rivers were also affected. In Slovakia, over 100 towns and villages were battered. In the remaining of April, Romania and Bulgaria were also hit by large floods.

\section{Concluding remarks}

In the perception of the public in Germany, Austria, and the Czech Republic, the winter of 2005/06 was snowy, cold and long. We have shown that this view does not with- 


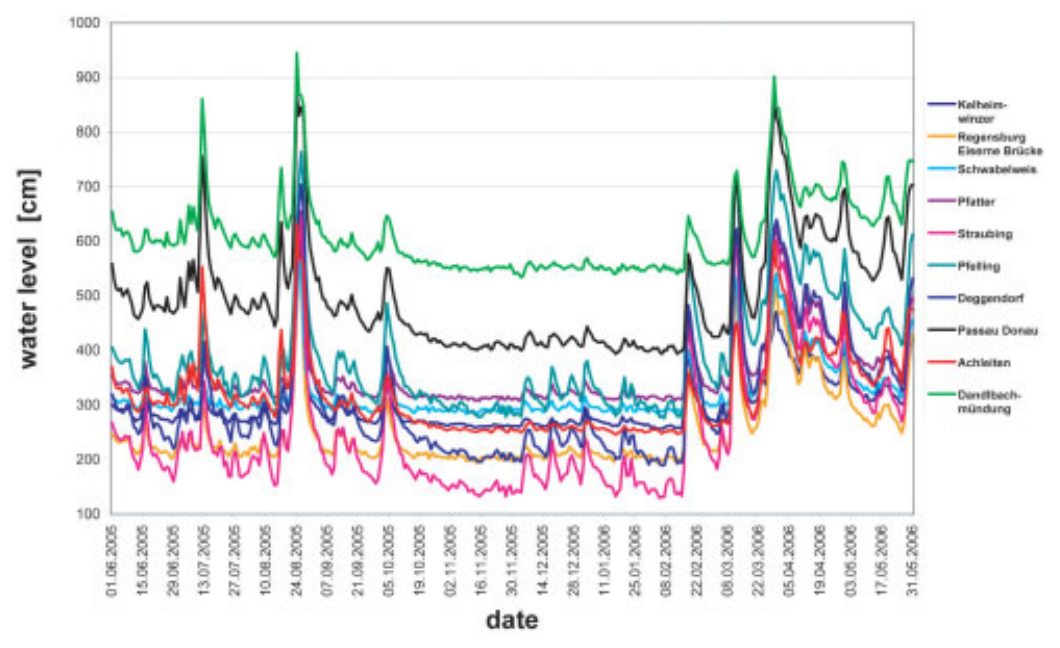

Figure 8. Flood waves for the River Danube between 1 June 2005 and 31 May 2006. Peak values given in $\mathrm{cm}$. The black line corresponds to Passau.

stand a climatological assessment. The contrariwise perception derives partially from the fact that extreme snow accumulations have become infrequent in recent decades. In fact, the winter was notable only in terms of the scarcity of significant thawing episodes. The recurrent blocking situation west of central Europe gave rise to synoptic patterns that kept the temperatures somewhat below freezing and caused average precipitation mostly in the form of snow. Among the circulation patterns, two stood out in terms of persistence: a cyclonic northwesterly flow and a trough situation over central Europe. Interestingly, the snow accumulation was extraordinary only on the lower regions examined (i.e. under $1000 \mathrm{~m}$ altitude), and accumulated snow at alpine peaks was at or below average throughout the winter (cf. Figure 6). For example, snow depths at the main divide of the eastern Alps in Austria were about $10-20 \%$ below the long-term mean at the end of the accumulation period at the end of May 2006 (Slupetzky, 2006). This made the glaciers in this area especially vulnerable to the heatwave of the century in July 2006.

People in central Europe have experienced a number of weather extremes in recent years (e.g. the River Elbe flood in summer 2002 (Ulbrich et al., 2003a, b), the summer heat of 2003 (Fink et al., 2004), the snowy winter described here and the alltime record heat of July 2006 (cf. http:// www.deutscherwetterdienst.de/de/Zusatz menues/Presse/Mitteilungen/PM20060728. pdf for Germany; http://www.zamg.ac.at for Austria). Not surprisingly, these events stirred up climate change discussion and the public may be tempted to assume that winters like 2005/06 belong to the types of extreme events that may occur more frequently in a warming world. Results from global climate models predict, however, an increase in both cyclonic and anticyclonic zonal circulation patterns over Europe at the end of this century, with, for example, significantly lower blocking frequencies over Europe (cf. Pinto et al., 2006, their Figure 7) and reduced frequencies of synoptic weather types GWLS 8 and 17 (Piecha and Krüger, personal communication). A recent study with the high resolution model REMO (Jacob 2001) displays a substantial winter warming of up to 3-4 degC in the Alpine foreland, along with an increase of precipitation (available at http://www. umweltbundesamt.de/uba-info-presse/ hintergrund/Klimaaenderungsworkshop. pdf) which (due to the enhanced temperature) falls less frequently as snow. As a consequence of the warmer winters, the simulation predicts a significant reduction of both the number of ice and frost days (days with maximum and minimum temperatures below $0^{\circ} \mathrm{C}$, respectively) for the end of the twenty-first century. If this holds true, winters like the one described in this study will be less likely to occur in the low elevation regions affected.

\section{Acknowledgments}

The authors would like to thank J. U. Belz and W. Wiechmann of the German Federal Institute of Hydrology (Koblenz) for providing Figure 8 and for their readiness to reply to our questions. Furthermore, we thank Deutscher Wetterdienst (German Weather Service) for providing daily data from several climate stations. We also thank V. Ermert and M. Reyers for preparing Figures 3, 5, 7. We also thank K. Mühldorf for providing the picture displayed in Figure 2. We thank the MPI for Meteorology by order of the Federal Environmental Agency, who kindly provided the ECHAM5 and REMO data and the DKRZ/WDCC for providing computer capacity. Finally, we would like to thank the anonymous reviewer for the comments which helped to enhance the manuscript.

\section{References}

Fink A, Brücher T, Krüger A, Leckebusch GC, Pinto JG, Ulbrich U. 2004. The 2003 European summer heatwaves and drought - synoptic diagnosis and impacts. Weather, 59: 200-216.

Folland CK, Parker DE, Scaife AA, Kennedy J, Colman A, Brookshaw A, Cusack S, Huddleston MR. 2006. The 2005/06 winter in Europe and the United Kingdom: Part 2: Prediction techniques and their assessment against observations. Weather, 61: 337-346.

Hess P, Brezowsky H. 1977. Katalog der Großwetterlagen Europas, Bericht des Deutschen Wetterdienstes Nr. 113: Vol.15, 2. Auflage, Selbstverlag des Deutschen Wetterdienstes, Offenbach am Main.

Jacob D. 2001. A note to the simulation of the annual and interannual variability of the water budget over the Baltic Sea drainage basin. Meteorology and Atmospheric Physics, 77: 61-73.

Pinto JG, Ulbrich U, Leckebusch GC, SpangehI T, Reyers M, Zacharias S. 2006. Changes in storm track and cyclone activity in three SRES ensemble experiments with the ECHAM5/MPI-OM1 GCM. Clim. Dyn. Submitted.

Rudolf B, Matthäus H. 2006. Das Frühjahrshochwasser der Elbe 2006 aus hydrometeorologischer Sicht. DWD.

Available from www.dwd.de/en/

FundE/Klima/KLIS/int/GPCC/Reports Publications/QR/Fruehjahrshochwasser_ 2006_Ru_Ma2.pdf

Saunders MA, Lea AS. 2006. The 2005/06 UK and European winter: the UCL forecast and its assessment against observations. Weather, 61: 347-352.

Slupetzki H. 2006. Konkursverfahren: Treibt der verstärkte Treibhauseffekt die Alpengletscher in die Insolvenz? Bergauf, 61 (131): 6-8.

Tibaldi S, Molteni F. 1990. On the operational predictability of blocking. Tellus, 42A: 343-365.

Ulbrich U, Brücher T, Fink A, Leckebusch GC, Krüger A, Pinto JG. 2003a: The Central European Floods in August 2002. Part I: Rainfall periods and flood development. Weather, 58: 371-377. Ulbrich U, Brücher T, Fink A, Leckebusch GC, Krüger A, Pinto JG. 2003b: The Central European Floods in August 2002. Part II: Synoptic causes and considerations with respect to climate change. Weather, 58: 434-442.

Correspondence to: Dr Joaquim G. Pinto, Institute for Geophysics and Meteorology, University of Cologne, Kerpener Str. 13, 50923 Köln, Germany

e-mail:jpinto@meteo.uni-koeln.de (c) Royal Meteorological Society, 2007 doi: 10.1002/wea.19 